\title{
Effects of a video-mediated student-centered learning environment on students' understanding of plant pathology principles
}

\author{
Erik-Ray Matthew S. Palomar ${ }^{12}$ and Rotacio S. Gravoso ${ }^{2}$ \\ 'Philippine Rice Research Institute, Muñoz, Nueva Ecija and 'Department of \\ Development Communication, Leyte State University, \\ Baybay, Leyte, Philippines
}

\begin{abstract}
Palomar, E. R. M. S. and R. S. Gravoso. 2006. Effects of video-mediated student-centered learning environment on students' understanding of plant pathology principles. Ann. Trop. Res. 28(2):32-52.

Working with the faculty of Plant Protection, a video-mediated learner-centered learning environment was designed, implemented, and evaluated in a PPrt 21 (Principles of Plant Protection) class. Students' learning outcomes, measured in terms of conceptual understanding and knowledge transfer, were compared with students in the control group who studied the same topics in a traditional learning environment.

Post-test results showed highly significant differences between the experimental and the control groups in terms of conceptual understanding and knowledge transfer, with the experimental group scoring higher than the control group.

Based on feedback, the learning environment did not only enrich students' understanding of plant diseases. It also promoted development of skills in teamwork, communicating, researching, and problem-solving. The students and the teacher suggested the use of this type of learning in other subjects.
\end{abstract}

Keywords: learning outcomes, student-centered learning, constructivist learning, video-mediated learning, plant pathology

Correspondence: R. S. Gravoso Present Address: Department of Development Communication, Leyte State University, Baybay, Leyte, Philippines 6521-A Tel No (053) 335-2650 


\section{INTRODUCTION}

Efforts to improve the quality of student learning have suggested the need for the use of learning technologies. The reason for this is based on these technologies' potentials to improve learning. According to Bollentin (1998), learning technologies offer more customized learning environments, whereas the traditional classroom-based education suits only a small percentage of the learning population.

Literature, however, shows that for technology to support effective learning, it has to be designed based on the constructivist model. This means that technologies have to be ubiquitously integrated into a learning environment where students actively construct their own knowledge in collaboration with their co-learners, teachers, and experts. In short, instead of just serving as sources of information, technologies should play the following roles: as a context to support learning-by-doing, as a tool to support knowledge construction, as a vehicle for exploring knowledge to support learning-by-constructing, as an intellectual partner to support learning by reflecting, and as a social medium to support learning through conversation and interaction which would contribute significantly to learning (Jonassen et al., 1999).

As a context to support learning-by-doing, technologies aim to provide learners with situations from which they can solve problems and explore knowledge. Thus, instead of conveying information, technologies present learners with a problem to explore. In their role as a support for knowledge construction, technologies assist learners' efforts to construct their own meanings. This means that technologies become tools for representing learners' ideas, perceptions, conceptions, and beliefs.

As a vehicle for exploring knowledge to support learning-byconstructing, technologies provide learners with information resources that they can use in constructing knowledge. Being an intellectual partner to support learning by reflecting, technologies are used to extend learners' capacities by using them as cognitive tools that engage them in thinking while constructing knowledge. The aim is to make students think critically about the things they are learning - that is, to reflect on their learning and how they learn. As a social medium to support learning through conversation and interaction, technologies provide learners with an opportunity to interact with their classmates and peers during the learning process. Examples are discussion 
groups where students are able to gain broader perspective of a certain knowledge domain from their peers from other countries.

As a state university dedicated to develop human resources for agroindustrialization and poverty alleviation, the Leyte State University (LSU) offers a number of courses to provide students with skills applicable in the field. One of these is PPrt 21 (Principles of Plant Protection), a course that introduces students to the nature, causes, and control of plant diseases. Based on students' feedback, however, they have difficulty studying the course as it involves many technical and scientific names to memorize, it has a tight schedule to cover all the topics, and they think that the course would not be useful to their chosen field of specialization.

Considering the above problems, PPrt 21 provides a good case for the application of the innovative learning like the student-centered learning approach. Growing out from the constructivist learning perspective, the student-centered learning approach promotes active learning, participation, and integration of knowledge learned by students from other courses. Learning proceeds not through lectures but by posing students with a problem for exploration. Students discuss to come up with the solution. In this process, students come to understand why, when, and how to use various concepts and strategies (Brown et al., 1989).

This study pilot-tested the use of a video-mediated learner-centered learning environment on students' understanding of plant pathology principles. To provide the challenge, students were shown with video documentaries featuring experiences with plant diseases. Students were asked to identify the diseases, their causal agents, and recommend methods for prevention and control. Their learning outcomes - measured in terms of conceptual understanding and knowledge transfer - and learning experiences were compared with students who studied the same topics in a traditional learning environment.

This study is important for several reasons. For one, developed learning materials that may serve as functional models for teachers as they design innovations in their classes. The study could also spark other researchers to conduct research on innovative learning approaches. In the Philippines where the dominant pedagogical strategy is didactic, there is a need for information on the value of the use of non-conventional learning. Hopefully, these studies could lead teachers to shift from the didactic to interactive learning. 


\section{MATERIALS AND METHODS}

\section{The research setting}

The learning environment was designed for and implemented in a threehour laboratory class in PPrt 21. The class is part of the required program of study for students taking up BS in Agriculture, BS in Agribusiness, BS in Development Communication, and BS in Agricultural Engineering programs at LSU. As an introductory course, the class aims to introduce students to the principles of plant protection and covers topics on the concepts of plant disease, symptoms and signs, diagnosis and Koch's postulate, groups of plant pathogens, disease development, and methods of disease control.

To design and implement the learning environment, the assistance of the faculty of the Department of Pest Management (DPM) was tapped. More specifically, DPM reviewed the learning activities and video materials. This was done to ensure that the activities jibed with the course objectives. DPM also assigned an instructor who, in turn, implemented the learning activities and taught the regular class.

\section{Design of the learning units and the videos}

In consultation with the professors of the course, it was decided that the learning units focus on basic Plant Pathology principles. Aimed to develop students' skills in diagnosis, the learning activities were based on the exercises of the Plant Protection 21 Laboratory Manual. A teaching guide entitled, PDi (Plant Disease Investigation) was developed. The specific exercises were on non-parasitic agents of plant disease, parasitic agents of plant diseases, and collection and preservation of diseased plant materials (Table 1).

The learning activities had videos that presented the problem to be solved by the students. The learning activities in the $P D i$ served as bases for developing the videos. To achieve authenticity, the videos were shot in areas with plants exhibiting symptoms of the diseases targeted for the students to learn. The plant specimens used in the traditional PPrt 21 laboratory exercises were the ones featured in the video.

Consistent with the constructivist learning view, the videos were designed 
Table I. Summary of the activities implemented in the video-mediated student-centered leaming environment

\begin{tabular}{|c|c|c|}
\hline Title of Activity & Focus & Objectives \\
\hline $\begin{array}{l}\text { Doctor. Doctor } \\
\text { the Plant is Sick }\end{array}$ & $\begin{array}{l}\text {-Non Parasitic } \\
\text { agents of plant } \\
\text { disease }\end{array}$ & $\begin{array}{l}\text { Students should be able to: } \\
\text { - identify the characteristics by non- } \\
\text { parasitics agents and } \\
\text { - recommend prevention and control } \\
\text { methods for the diseases }\end{array}$ \\
\hline $\begin{array}{l}\text { Getting to Know } \\
\text { the Enemy }\end{array}$ & $\begin{array}{l}\text {-Parasitic agents } \\
\text { of plant disease } \\
\text { - Symptoms } \\
\text { - Preservation } \\
\text { of diseased } \\
\text { specimen }\end{array}$ & $\begin{array}{l}\text { Students should be able to: } \\
\text { - recognize the symptoms exhibited } \\
\text { by different plant pathogens } \\
\text { on host plants } \\
\text { - recomend prevention and control } \\
\text { methods for the diseases } \\
\text { - identify the diseases infecting the } \\
\text { plant samples, and } \\
\text {-preserve collected diseased specimens } \\
\text { of different crops using appropriate } \\
\text { methods }\end{array}$ \\
\hline I Saw the Sign & $\begin{array}{l}\text { - Signs of } \\
\text { agents of } \\
\text { plant disease }\end{array}$ & $\begin{array}{l}\text { Students should be able to: } \\
\text { - recognize the signs exhibited by } \\
\text { different plant pahtpogens on host plants, } \\
\text { and } \\
\text { - perform the steps involved in routine } \\
\text { plant disease diagnosis }\end{array}$ \\
\hline
\end{tabular}

Table 2. Features of the video materials used in the study

Features Advantages

Documentary format

The documentary format allowed for the realistic presentaiton of events.

Situated in actual and real situations

Presented a problem for the students to explore

The videos presented problems which occur in a local setting. It helps the students realize the importance of the topic.

The problem motivated students to learn as they were challenged to solve it. 
Table 3. Sypnoses of the video material used

Screen capture Sypnosis

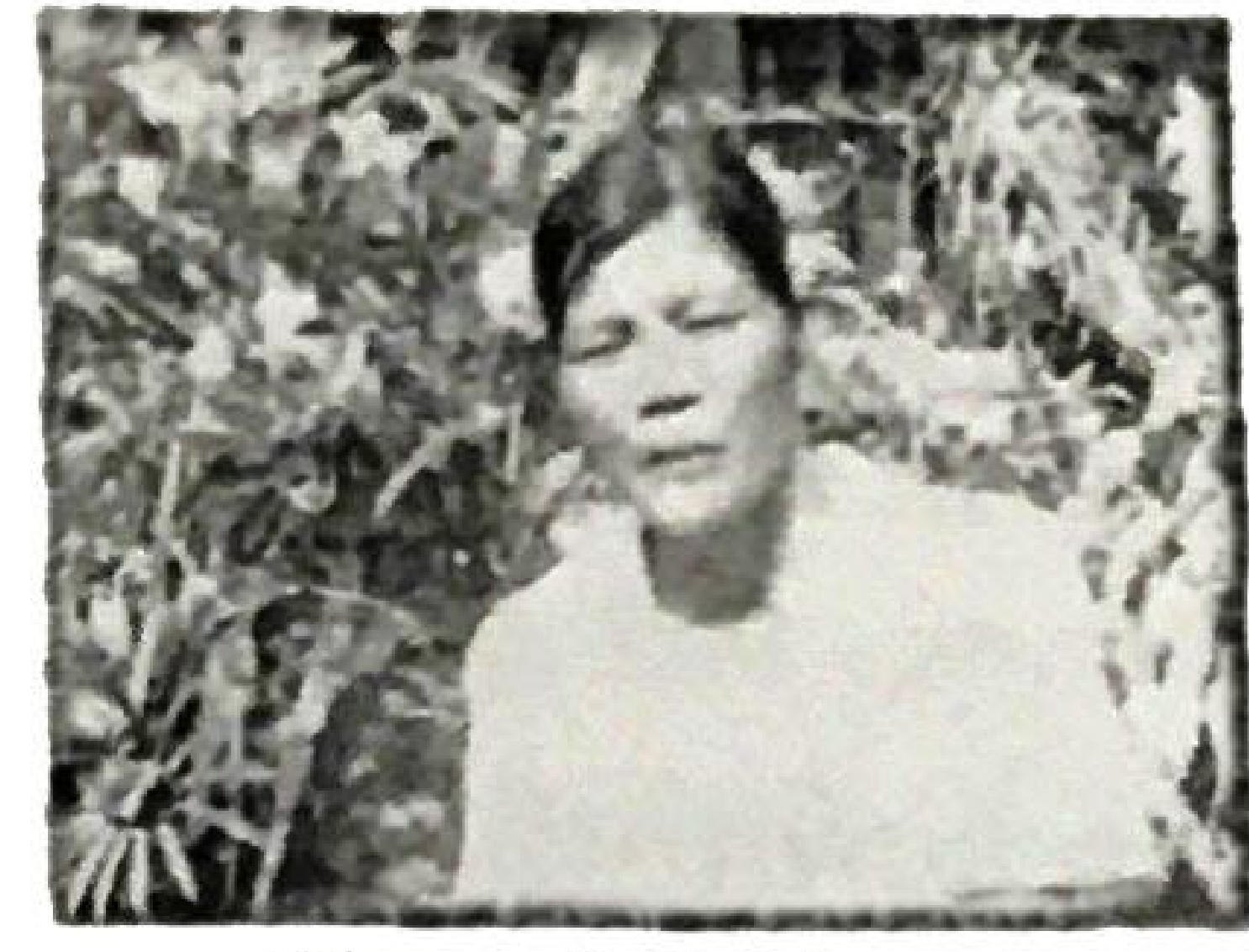

Planted Evidence

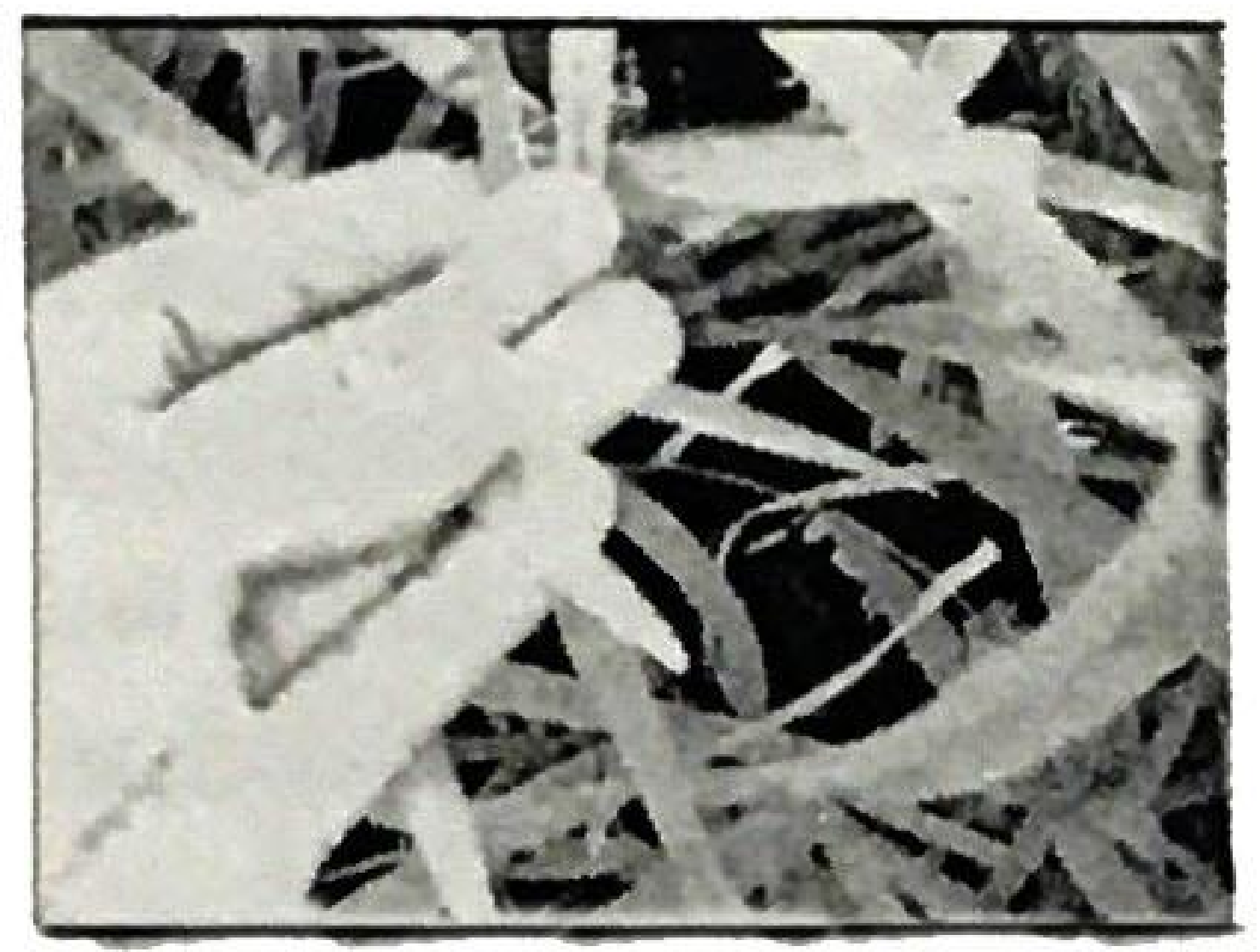

Cereal Killer

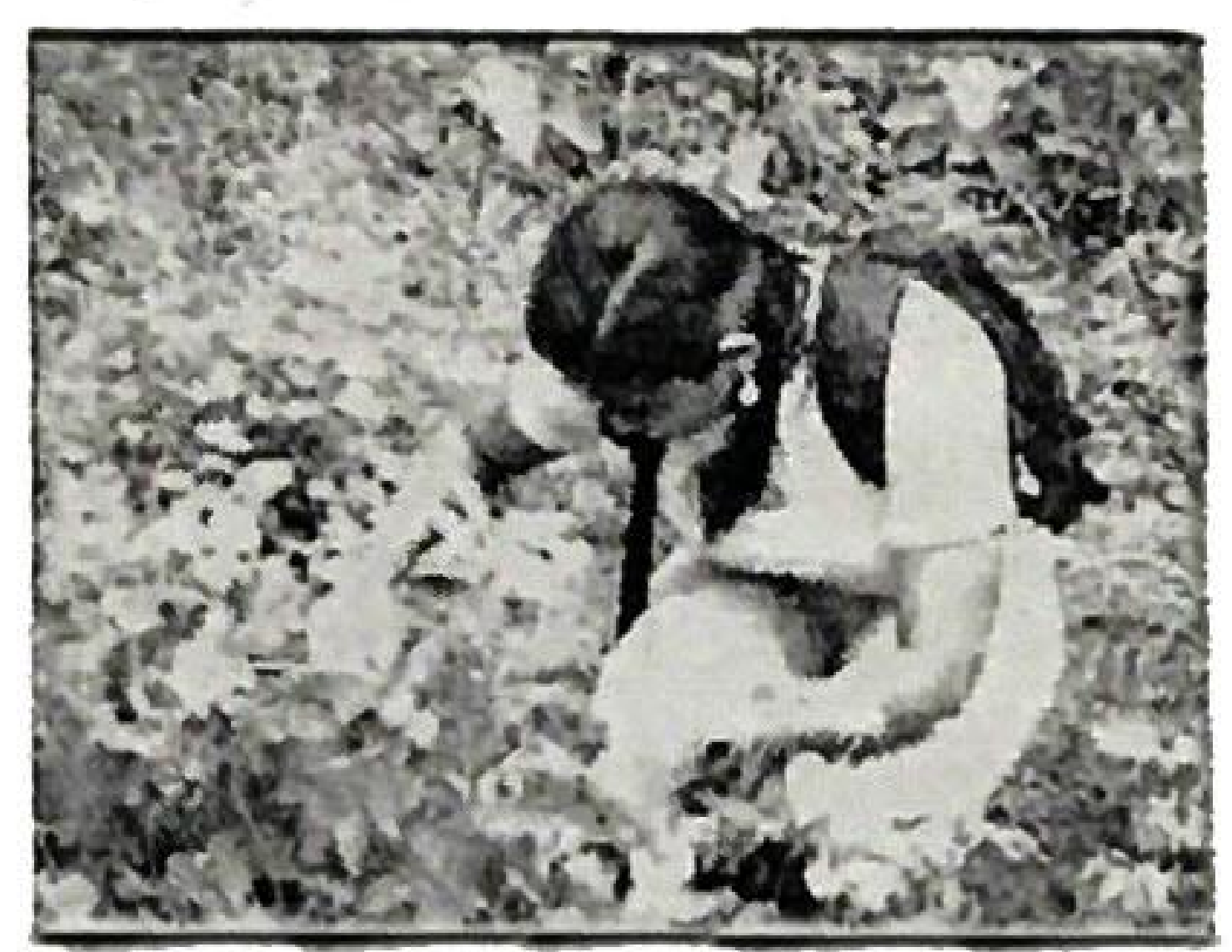

A Case of Mistaken Identity
Planted Evidence features the experiences of a mother who tries vegetable growing to earn a living for her family. She, however, experienced problems with her plants when they developed disease symptoms. These symptoms were either caused by environmental factors or by improper management practices. Students had to identify the diseases based on the symptoms, give the cause of the disease, and give the method of control.

The video, Cereal Killer, features a farmer unfamiliar with appropriate pest management techniques. $\mathrm{He}$ became troubled when his crops were attacked by disease. The students were asked to help the farmer by identifying the diseases based on the symptoms, giving the causal organism, presenting pest management recommendations, and supporting their answers.

A Case of Mistaken Identity shows student growing peanut to obtain a picture showing improper agricultural practices. She tried to control the disease by consulting a book from the library. Unfortunately, the control method did not cure the plants from the disease. The reason must be determined by the student. They must also determine how to ensure correct disease diagnosis. 
to promote generative learning and facilitate collaboration. Thus, unlike the traditional instructional videos which just narrate information just as a teacher would, the videos used in the class showed experiences of farmers who have disease problems with their crops. From the situations presented in the video, the students had to identify the diseases, the causes, and recommend methods of prevention and control. Tables 2 and 3 present the characteristics and synopses of the video materials used.

\section{Implementation and evaluation of the learning environment}

Working in groups, students studied the unit for three weeks - that is, for three meetings. In the first meeting, they used the video, Planted Evidence and during the second meeting, Cereal Killer. In the third meeting, the video was Mistaken Identity. As additional information, handouts containing the videos' summary and other pertinent information about the farmer's practices were distributed. In these three meetings, students were asked to identify the diseases, their causal agents, and recommend methods for prevention and control. While answering the tasks, students were given freedom to consult with their teacher.

In the classes, selected groups were asked to report their outputs. After each group presentation, interaction ensued with the teacher as moderator. The main characteristic of the interactions was challenging the groups' stand. The group, on the other hand, tried to defend their position. At the end of the presentations, the teacher summarized the discussions. In this summary, the teacher corrected the misconceptions gleaned from the students' interactions.

After the implementation of the instructional intervention, a post-test was administered both in the control and the experimental groups. The questions were similar to the pre-test that is, they focused on the identification of noninfectious and infectious diseases and the identification of symptoms and signs. Consistent with the constructivist learning view, assessment of learning outcomes required students to identify the disease and recommend appropriate treatments. Answers were evaluated by the instructor following the structured observable learning outcomes (SOLO) by Biggs (1996). Table 4 presents Biggs' SOLO taxonomy. 


\section{RESULTS AND DISCUSSION}

\section{Respondents}

Respondents in this study included 65 PPrt 21 students. Their ages ranged from 17 to $24(M=18.42 ; S D=1.81)$. More than half $(61.5 \%)$ were females and the rest were males $(38.55 \%)$. During the pre-test, the one-way ANOVA showed that the experimental and the control groups were not significantly different in terms of: identifying non-infectious plant diseases $(t(63)=0.76$, $\mathrm{p}>.05)$, identifying infectious plant diseases $(t(63)=.45, \mathrm{p}>.05)$, and identifying symptoms and signs $(t(63)=0.16, \mathrm{p}>.05)$. This implies that prior to the instructional intervention, students in the control and experimental groups were equal in terms of their knowledge and skills in identifying non-infectious and infectious plants diseases and symptoms and signs.

\section{Learning outcomes}

Students' incremental scores (taken by subtracting the pre-test from the post-test scores) were used as a measure for improvement of learning outcomes. Using these scores, the t-test showed highly significant difference between the experimental and the control groups. More specifically, the t-test yielded a highly significant difference between the control and the experimental groups $(t(63)=6.23, \mathrm{p}<0.01$ and $(t(63)=8.60, \mathrm{p}<0.01$, respectively) in terms of students' incremental scores in the identification of non-infectious infectious diseases. In both tasks, the experimental group scored higher than the control group $(M=1.11, S D=0.99 ; M=-0.2, S D=0.76$, respectively and $M=1.49, S D=0.61 ; M=0.4, S D=0.89$, respectively). For the identification of symptoms and signs, results showed significant difference between the control and the experimental groups $(t(63)=2.61, \mathrm{p}<0.05)$. In this task, the experimental group had higher scores than the control group ( $M$ $=1.149, S D=1.22 ; M=0.5, S D=1.04$, respectively).

When the mean incremental scores were classified into high (2.67-4), average (1.34-2.66), and low (0-1.33), a large proportion (66.67\%) of control group students had low mean incremental scores. On the other hand, the experimental group students had average mean incremental scores. Some even 
Table 4. Guide for evaluating students' conceptual understanding (from Biggs, 1996)

\begin{tabular}{|c|c|c|}
\hline Score & SOLO level & Description \\
\hline 1 & Pre-structural & $\begin{array}{l}\text { Answers present unconnected } \\
\text { information and generally make no sense. }\end{array}$ \\
\hline 2 & Unistructural & $\begin{array}{l}\text { Answers make simple and obvious } \\
\text { connections, but their significance is not } \\
\text { grasped. }\end{array}$ \\
\hline 3 & Multistructural & $\begin{array}{l}\text { Answers make a number of connections, } \\
\text { but the meta-connections between them } \\
\text { are missed, as is their significance in } \\
\text { relation to the whole. }\end{array}$ \\
\hline 4 & Relational level & $\begin{array}{l}\text { The answer shows student's appreciation } \\
\text { of the significance of the parts in relation } \\
\text { to the whole. }\end{array}$ \\
\hline 5 & $\begin{array}{l}\text { Extended } \\
\text { abstract level }\end{array}$ & $\begin{array}{l}\text { The student is making connections not } \\
\text { only within the given subject area, but } \\
\text { also beyond it, able to generalize and } \\
\text { transfer the principles and ideas } \\
\text { underlying the specific instance. }\end{array}$ \\
\hline
\end{tabular}

Table 5. Percent distribution of SOLO levels of the students in the post-test

\begin{tabular}{lllllll}
\hline SOLO levels & 1 & 2 & 3 & 4 & 5 & 6 \\
\hline
\end{tabular}

Non-parasitic diseases

$\begin{array}{lllllll}\text { Control group } & 0 & 50.0 & 26.7 & 23.3 & 0 & 0 \\ \text { Experimental group } & 0 & 2.9 & 20.0 & 60.0 & 17.1 & 0\end{array}$

Parasitic diseases

$\begin{array}{lllllll}\text { Control group } & 0 & 33.3 & 56.7 & 10.0 & 0.0 & 0 \\ \text { Experimental group } & 0 & 0 & 14.3 & 80.0 & 5.7 & 0\end{array}$

Symptoms and signs

$\begin{array}{lllllll}\text { Control group } & 3.3 & 63.3 & 10.0 & 20.0 & 3.3 & 0 \\ \text { Experimental group } & 0 & 31.4 & 28.6 & 25.7 & 14.3 & 0\end{array}$

(Note: 1 - No answer; 2 - Prestructural; 3 - Unistructural; 4 - Multistructural; 5 - Relational; 6 - Extended abstract) 
had high mean incremental scores. Figure 1 shows the pre- and post-test scores of the control and experimental groups.

The SOLO taxonomy also showed differences between the control and the experimental groups in terms of the quality of explanation (Table 5). For instance, while most answers of the control group students were in the prestructural level, those in the experimental group were already in the multistructural level $(60 \%)$. A few $(17.1 \%)$ reached the relational level.

A similar trend was observed in the answers for parasitic diseases. Two students $(5.7 \%)$ of the experimental group produced an answer that qualified for the relational level. For the control group, the highest level reached was multistructural $(10 \%)$. Most were in the unistructural $(56.7 \%)$ and prestructural $(33.33 \%)$ levels. For the identification of symptoms and signs, many answers in the experimental group were at the multistructural level (25.7\%). In fact, more than a tenth $(24.3 \%)$ reached the relational level. For the control group, only one answer $(3.3 \%)$ reached the relational level. A great proportion of the answers were yet at the pre-structural level (63.3\%).

\section{Knowledge transfer}

The bottomline of learning is developing students' ability to apply their knowledge in novel situations. In learning research, this phenomenon is called knowledge transfer.

Results showed that students who studied in the video-mediated learnercentered learning environment were better in applying what they learned in real life situations, as seen in the highly significant difference between the scores of the control and the experimental groups in the three tasks - diagnoses of root-knot nematode in vegetable $(t(63)=2.73, \mathrm{p}<0.01)$, virus disease in sweetpotato $(t(63)=2.33, \mathrm{p}<0.05)$, and sunscald in palm $(t(63)=3.7, \mathrm{p}<0.01)$. The students in the experimental groups were able to find the answers better than the students in the control group. In the traditional class where the students were given a list of common diseases, the students did not know how to diagnose diseases that were unknown to them. Figure 2 shows the knowledge transfer scores of the students in the control and the experimental groups. The tasks were on identifying non-infectious disease, infectious disease, and signs and symptoms. 

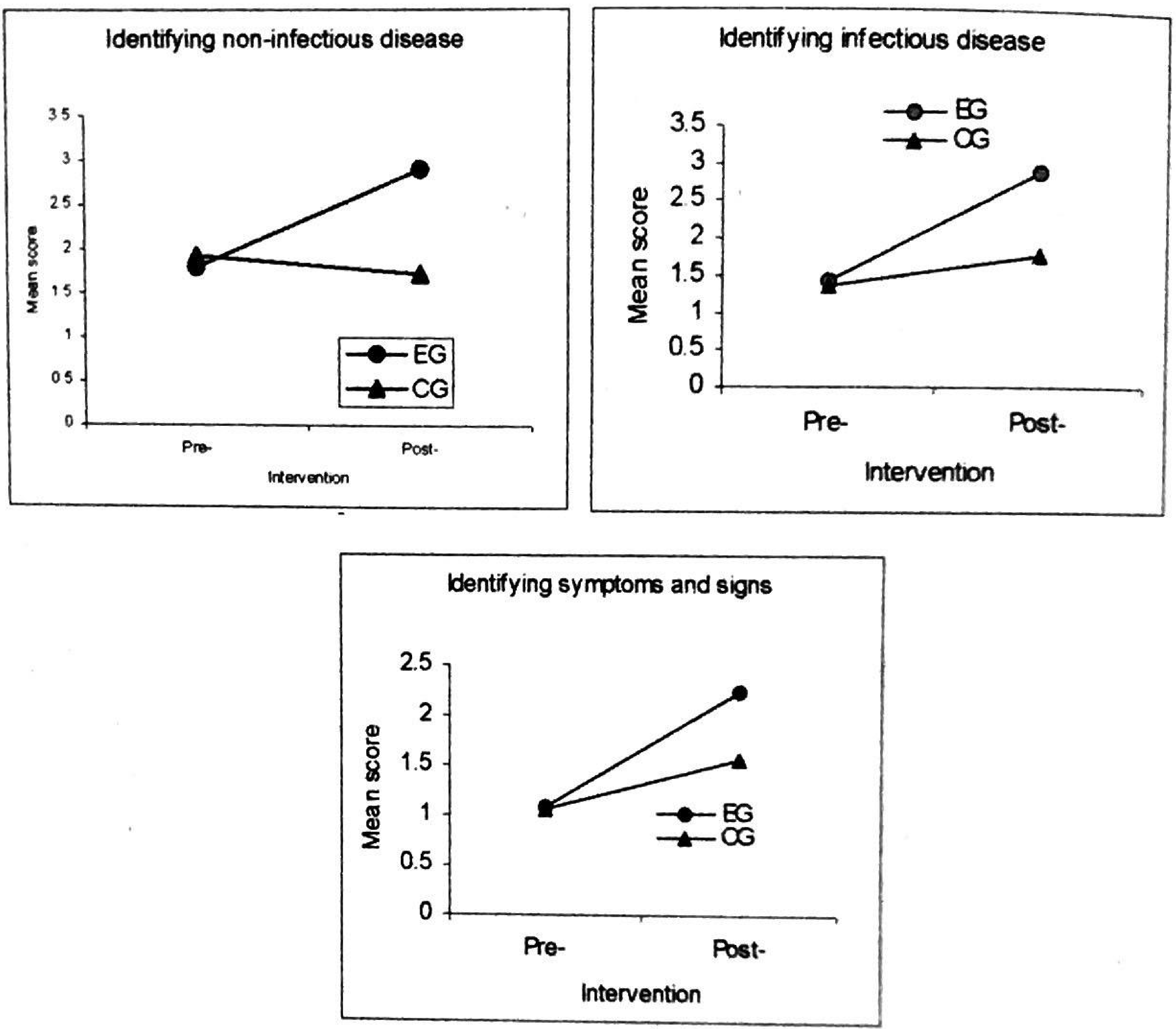

Fig. 1. Pre- and post-test and knowledge of students in the experimental (EG) and control (CG) groups.

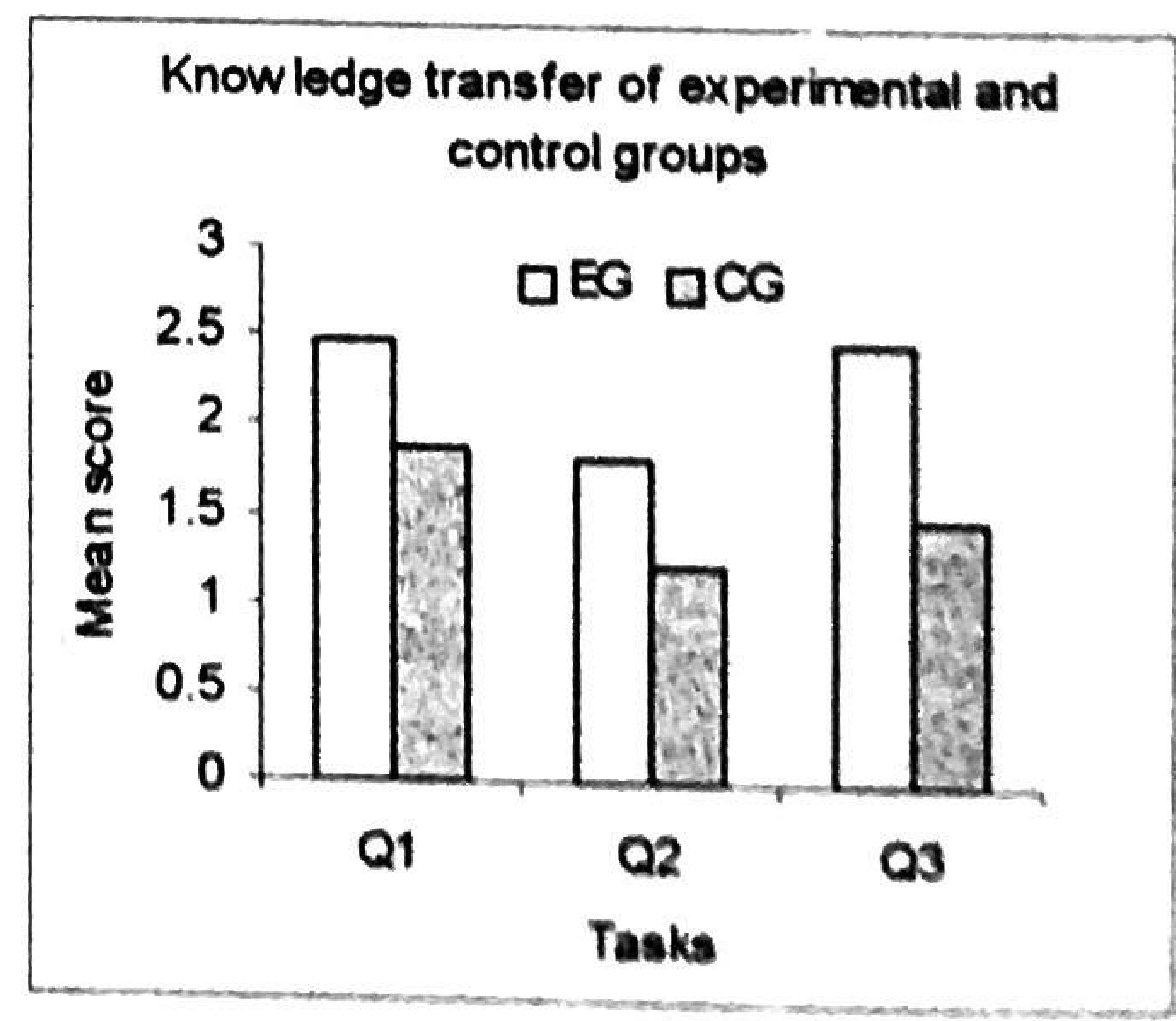

Fig. 2. Knowledge transfer scores of students in the experimental (EG) and control (CG) groups ((Note: Q1 - identifying non-infoctious disease, Q2 - identifying noninfectious disease: Q3 - identifying signs and symptoms.) 
In terms of SOLO, Table 6 shows that while most of the answers of the control group students were still at the prestructural and unistructural levels, those in the experimental group have reached the multistructural and relational levels. For example, for the root-knot nematode disease in vegetables, a great percentage of the answers of the control group students belonged to the prestructural (40\%), unistructural (36.7\%), and multistructural (37.1\%) levels. Only a negligible few (3.3\%) reached the relational level. In the experimental group, however, most answers fell into the unistructural $(31.4 \%)$, and multistructural $(37.1 \%)$ levels. More than a tenth $(14.3 \%)$ reached the relational level.

A similar trend was observed for the virus disease in sweetpotato. A great proportion (73.3\%) of students in the control group had answers in the prestructural. In the experimental group, however, a number (20\%) reached the relational level. In the control group, no answer belonged to the relational level.

With regard to the identification of the sunscald of palm, more than half $(56.7 \%)$ of the answers of the control group students were still at the prestructural level. But for the experimental group, more than a fourth (28.6\%) reached the relational level. Box 3 presents typical examples of students' answers.

Comparing experimental group students' performance with students taking up Plant Protection as their major field (i.e., had taken PPrt 21 and were taking advanced plant protection courses during the conduct of the study), results showed that the answers of the experimental group were almost similar with the answers of major students. The majors offered more facts, especially in the development of the diseases.

In the knowledge transfer test, the experimental group was able to correctly identify the diseases and include key information. Their answers, however, lacked a comprehensive discussion on the cause of the disease. The major students practically filled every box in the answer sheet. However, some were just stating facts and not relating these facts to the situation presented. Some even included the geographical distribution of the disease. The test, however, revealed that some students did not grasp the situation in context since they were not able to identify some diseases correctly. They confused common symptoms for other diseases since they did not consider the events 
Table 6. Typical examples of answers of students in the experimental group in the knowledge transfer test (Task: identifying non-infectious disease)

Level Answer

Prestructural "The disease that attacked the okra plants is the Pseudomonas solanacearum. The cause of this disease is due to the excessive light of the sun or high temperature. It can be prevented by cultural method" (Student 33).

Unistructural "The disease is caused by Meloidogyne incognita, a nematode. It can be controlled by spraying and by crop rotation" (Student 2).

Multistructural "The disease that attacked the tomato plants was root galls. The disease is caused by Meloidogyne incognita which attacked the roots of the plant. To control this disease, Aira should use eradication, sanitation, cultural practices and biological control" (Student 20).

Relational "The disease that attacked the plant is a plant parasitic nematode associated with root-knot nematodes (Meloidogyne incognita) which are known as a wide-spread and diverse group of plant parasitic nematodes. Control methods should be used to keep nematode numbers below damaging levels instead of trying to eradicate these organisms. Host plants are able to compensate for damage caused by moderately high numbers of nematodes, especially where the plants are grown under optimum environment conditions although nematodes such as root-knot nematode may establish hundreds of galls on a root system. In these cases, it needs to predict the nematode hazard to anticipated crops and to recommend cultural practices" (Student 9).

stated in the situations. Table 7 presents the descriptions of the experimental group's and the major students' answers.

\section{Feedback on the learning environment}

To obtain more in-depth information on the learning experiences of the students, interviews were conducted with students from the control and the experimental groups. Data were subjected to a phenomenographic analysis (Marton and Booth, 1996). The analysis yielded six distinct categories of 
Table 7. Similarities and differences of the answers in the test for the experimental group and major students.

\begin{tabular}{lll}
\hline Quality of answers & $\begin{array}{l}\text { Experimental } \\
\text { Group }\end{array}$ & $\begin{array}{l}\text { Major } \\
\text { Students }\end{array}$ \\
\hline $\begin{array}{l}\text { Depth of explanation } \\
\text { Although some answers } \\
\text { were able to reach the } \\
\text { relational level, students' } \\
\text { explanation still fell short } \\
\text { of the explanations of } \\
\text { major students. }\end{array}$ & $\begin{array}{l}\text { Major students had } \\
\text { more facts in their } \\
\text { explanations from } \\
\text { their major subject } \\
\text { (PP111). However, }\end{array}$ \\
& $\begin{array}{l}\text { explanation did not } \\
\text { include information } \\
\text { from other related fields. }\end{array}$ \\
Mccuracy & $\begin{array}{l}\text { Most of the students } \\
\text { were able to answer } \\
\text { the questions. }\end{array}$ & $\begin{array}{l}\text { Several major students } \\
\text { were not able to } \\
\text { identify the second and } \\
\text { third diseases in the } \\
\text { knowledge transfer }\end{array}$ \\
& $\begin{array}{l}\text { test because they did } \\
\text { not grasp the situation } \\
\text { in context. }\end{array}$ \\
\hline
\end{tabular}

learning experiences. These learning experiences are presented in Table 8.

Despite the advantages experienced by the students in the learnercentered learning environment, they also perceived some problems. One of these was on the length of time allotted to perform the activities and come up with correct plant disease diagnosis and recommendations. According to the students, they needed more time, especially in the researching for information, since this was the first time they were exposed to this kind of learning activity. They felt that they lack the skills in looking for the answer. But they admitted that they experienced the difficulty in researching only during the first time they did it. During this time, the teacher gave guide questions or scaffolds to help them locate the disease in question. She also gave tips on how to research to save time.

Another major point raised by the students was the lack of information sources to serve as their reference in answering the questions presented by the video. They suggested that more materials be provided to them and that 
Table 8. Students' comments on the unit

\begin{tabular}{ll}
\hline Comments & Explanation \\
\hline
\end{tabular}

Situated in actual and real situations

Generative

Fostered cooperation and teamwork

Promoted development of communication skills and confidence

Motivates the student to participate and learn

Better retention of information

Promoted development of research and problemsolving skills
The learning activities and the videos presented problems which occur in a local setting. It helps the students realize the importance of the topic. They experience what experts do in their field.

Most of the ideas and discussion came from the students. Students generated their own ideas, identified the problems, and formulated solutions on their own.

The class was divided into groups of three. Working together allowed the students to consider the thoughts and ideas of others.

From their interaction and output presentations, students learned communication skills and developed their confidence.

The strategy was fun and enjoyable. It did not bore the students since they had to exert effort and participate and did not just sit and listen to the teacher.

Students remember the information for a longer time since they do not just memorize information but take time to understand them.

Through the problem-solving activity, the students learned how to look for information and use this information to solve the problem.

these materials should be distributed to the class. Making the materials available to them will not only help them find their answers but also help them finish the task earlier since they do not need to wait for the other groups to finish using the reading materials.

The other problem was related to difficulty in managing the class. In the unobtrusive classroom observations, the class was disorganized as students were walking back and forth and searching for the answers from the different 
materials distributed in the classroom. Noise was also tolerated since this was created by the group's interaction. However, one student said that it would have been less chaotic had they been a smaller class or if they were in a bigger classroom.

On the part of the teacher, she was fairly well-versed in her role in the classroom since she already took seminars on a similar teaching method, selflearning. She, however, realized that without somebody to help in the preparation of the class, that is, setting up the diseased specimens, the unit will be very laborious for the teacher. This becomes more of a problem because of the big class size. According to her, she prefers this strategy of teaching but is more motivated to use it with her classes with the Plant Protection majors because of their small number. For her, "there will always be a lot of limitations if the class size is big."

However, even with these shortcomings, results of the study showed the potentials of the constructivist approach in improving learning outcomes. Based on the feedback, the unit did not only help the students learn about plant pathology but also helped them develop necessary skills in communicating, researching, and problem-solving. It also instilled in them the values of hard work, motivation, cooperation, and teamwork. Furthermore, students' and the teacher's attitude towards the unit was favorable that they have suggested the use of this type of learning in other subjects. According to the students, the strategy has a huge advantage over the traditional teacher-centered learning. As one student put it, "We are sometimes easily confused listening to lectures. So, that new method was really better. The experience is different than just listening to lectures."

\section{IMPLICATIONS AND RECOMMENDATIONS}

Results of the study showed that students in the experimental group had consistently performed better than the control group in terms of conceptual understanding and knowledge transfer. In short, the video-mediated studentcentered learning was more effective than the traditional learning environment. Worth noting is that in just three weeks, skills in plant diseases diagnosis and understanding of the students were similar to students who had studied plant pathology for a longer period. These results highlight the fact that the video- 
mediated learner-centered learning environment was effective in improving students' understanding of plant pathology principles and enabling them to apply this understanding in novel situations.

The reason for the improvement of students' learning outcomes in the experimental group lies on the nature of learning these students have experienced. Being generative, the video documentaries posed students with a challenge for them to explore, that is, identifying the plant diseases. In the course of trying to come up with a solution, students engaged in discussion, thus enabling them to learn from each other. Likewise, when they presented their solutions, the teacher tried to correct the misconceptions that emerged, thus giving them a chance to correct their incorrect understanding. The effectiveness of this approach is explained in the mental repair model repair by Chi (2000) and the knowledge-in-pieces views by diSessa (1993), Ueno (1993), Smith et al. (1993), and Hammer (1996). The mental repair view holds that constructive (or generative), not didactic, instruction is more effective in leading students to fix or repair interpretations that run contradictory to the scientifically accepted conceptions. This approach, according to Chi, encourages students to reflect on their learning, leading them to detect inconsistencies and violations between their mental and normative models.

The knowledge-in-pieces perspective holds that knowledge is malleable and therefore, can be expanded. However, instruction that confronts or aims to replace misconceptions, as in lecturing, is insufficient to expand students' fragmented understanding. An appropriate strategy is like the one used by the experimental group, that is, giving the students an opportunity to discover for themselves the disparity between their understanding and the scientific conceptions.

In terms of knowledge transfer, scores of the students in the experimental group were significantly higher than the control group and the Plant Protection major students. As mentioned earlier, these major students had passed PPrt 21 the previous year and during the conduct of the study, were taking an advance course in plant pathology. This high knowledge transfer skills of students could be explained by the fact that learning in the experimental group was anchored on realistic situations. Based on their responses to the learning experiences questionnaire and in the in-depth interviews, the stories presented by the video documentaries are actually occurring in their communities. 
The potentials of situated learning to engender effective learning could be attributed to the fact that situating learning in realistic situations leads to deeper and richer understanding (Duffy and Cunningham, 2001). This subsequently results in conditioned knowledge (Bruer, 1994; Mandl et al., 1994), knowledge that includes a specification of the contexts where that knowledge is useful (Simon, 1989; Glaser, 1992). In short, the student-centered learning environment enhanced by video has cultivated practical knowledge, not inert knowledge that results from a learning environment stripped of context.

Based on the students' learning experiences, it would seem plausible to argue that the design of a learning environment was responsible for the improvement of students' learning outcomes. This argument is based on Gibson's (1977) theory of affordances and research into learning. According to the theory of affordances, learning environments provide activities for organisms. Likewise, learning research shows that different kinds of learning environments influence learning approaches and outcomes. For instance, if students perceive that their learning environment provides them with opportunities for deep learning, they will also use deep learning approaches. On the other hand, if they feel that their learning environment is affording superficial learning, they will also use surface learning approaches. Consistent with previous studies (Gravoso et al. 2002; Prosser and Trigwell, 1999), students in the experimental groups had better learning outcomes than the control groups. In short, students in the experimental groups had higher learning outcomes because they perceived the video-mediated student-centered learning as affording them with deep learning.

The above findings consistently underscore the need for a shift from didactic to constructivist design of instruction. Effecting this change, however, seems a gargantuan task. For one, a look at the classrooms today would show that the dominant teaching strategies are didactic in nature characterized by teachers transmitting their interpretations to students via lectures.

Laboratory classes are not spared by the non-functional instructional design. An examination of these classes would show that laboratory classes are designed as if they were a fait accompli, that is, students are presented with "precise set of steps to be executed in just the manner in which they were taught and then ritualistically practiced on a set of well-specified tasks until automaticity is achieved" (Alexander and Murphy, 1999, p. 569). 
To alleviate this problem, there is a need to orient teachers to the new modalities of teaching and the need to change their teaching strategies. Likewise, teacher-training programs should now begin reforms by integrating the altemative learning view into their curricular program.

The use of video materials also seemed to have influenced student learning. In fact, the videos were frequently cited by students as responsible for making learning more fun and interesting. This observation simply underscores the need to design instructional materials like the ones used in this study that is, learning materials that aim to promote knowledge construction, rather than transmit information. Based on the arguments of Bransford and Cocking (2000), if we will continue to use technology that transmit information, "money spent on technology and time spent by students using technology are money and time wasted" (p. 206).

It is, therefore, suggested that agencies and organizations mandated with development of technology for instruction start designing learning materials using the instructional materials used in this study as models. Likewise, making these materials available to teachers may promote instructional change. To help stop the vicious cycle of producing learning materials that result in poor learning outcomes, programs that produce such graduates as media specialists, instructional designers, and educational developers should now start subscribing to design models and theories grounded on learning research.

\section{LITERATURE CITED}

ALEXANDER, P. and P.K. MURPHY. 1999. Nurturing the seeds of transfer: A domainspecific perspective. International Journal of Educational Research, 31: 561576.

BIGGS, J. 1996. Learning outcomes in higher education. Studies in Higher Education, 21:93-108.

BOLLETIN, W.R. 1998. Can information technology improve education?: Measuring voices, attitudes and perceptions. OnTheInternet: 33(1). Retrieved May 20, 2005 from the Internet. http://www.educause.edu/apps/er/review/reviewArticles/ 33150.html

BRANSFORD, J.D., A.L. BROWN, and R.R. COCKING 2000. How people learn: Brain. mind, experience, and school. National Academy Press, Washington, D.C 
BROWN, J.S. L. COLLINS, and P. DUGUID. 1989. Situated cognition and the culture of learning. Educational Researcher, 18: 32-42.

BRUER, J.T. 1994. Schools for thought: A science of learning in the classroom. MIT Press, Cambridge.

CHI, M.T.H. 2000. Self-explaining expository texts: The dual processes of generating inferences and repairing mental models. In: Advances in instructional psychology. Volume 5: Educational design and cognitive science (R. Glaser, Ed.). Erlbaum, Mahwah, New Jersey, pp. 161-238.

DISESSA, A.A. 1993. Toward an epistemology of physics. Cognition and Instruction, 10:239-249.

DUFFY, T.M. and D.J. CUNNINGHAM. 2001. Constructivism: Implications for the design and delivery of instruction. In: Handbook of research for educational communication and technology (D.H. Jonassen, Ed.). Retrieved from the Internet on February 20, 2003. http://www.aect.org/Intranet/Publications/edtech\#index.

GIBSON, J.J. 1977. The theory of affordances. In: Perceiving, acting, and knowing (R. Shaw and Bransford, Eds.). Erlbaum, Hilsdale, New Jersey.

GLASER, (1992). Expert knowledge and processes of thinking. In: Enhancing thinking skills in the sciences and mathematics (D.F. Halpen, Ed.). pp. 63-73. Erlbaum, Hillsdale, New Jersey.

GRAVOSO, R.S., A.E. PASA, and T. MORI. 2002. Influence of students' prior learning experiences, learning conceptions and approaches on their learning outcomes. In: Research and development in higher education. Volume 25 - Quality conversations (A. Goody, J. Herrington, and M. Northcote, Eds.) pp. 282-289. ACT: Higher Education Research and Development Society of Australasia.

HAMMER, D.H. (1996). Misconceptions on p-prime: How many alternative perspectives of cognitive structure influence instructional perceptions and intentions? The Journal of the Learning Sciences, 5: 97-127.

JONASSEN, D.H. K.L. PECK, and, B.G. WILSON. 1999. Learning with technology: A constructivist perspective. Prentice Hall, Upper Saddle River, New Jersey.

MANDL, H. H. GRUBER, and A. RENKL. H., H. GRUBER, and A. RenkI. 1994. Knowledge application in complex systems. In: Technology-based learning environments. Psychological and educational foundations (S. Vosniadou, E. De Corte, and A Mandl, eds.). Springer-Verly, Berlin, pp. 40-47.

MARTON, F., and. S. BOOTH. 1996. The learner's experience of learning. In: Qualinative approaches to evaluation in education (D. Olson \& N. Torrance, Eds.). Pracger. 
New York. 176-205 pp.

PROSSER, M. and K. TRIGWELL. 1999. Understanding learning and teaching: The experience in higher education. SRHE Open University Press, Burckingham.

SIMON, H.A. 1989. Problem solving and evaluation. In: Problem solving and education: Issues in teaching and research (D.T. Tuma and R. Reif, Eds.), pp. 81-96. Erlbaum, Hillsdale, New Jersey.

SMITH, J.P., A.A. DISESSA, and A.A. ROCHELLE. 1993. Misconceptions reconceived: A constructivist analysis of knowledge in transition. The Journal of the Learning Sciences, 32: 115-163.

UENO, N. 1993. Reconsidering p-prime theory from the viewpoint of situated cognition. Cognition and Instruction, 10: 239-249. 